\title{
REINTERPRETASI SIMBOL BATIK DEMAK
}

\author{
Afrizal \\ Jurusan Kriya Seni, Fakultas Seni Rupa dan Desain \\ Institut Seni Indonesia (ISI) Surakarta \\ Email : afrizal@isi-ska.ac.id
}

\begin{abstract}
This article wants to reinterpret the symbol of batik Demak that has been lost for hundreds of years. Demak as the first Islamic empire, in its time, becomes the center of Islamic Javanese culture and a cultural figure with the various cultural products. One of the cultural products in Demak is batik. The context of this study views Batik Demak as a cultural form, namely artifacts that contain a discourse of self-representation found by ideographic aspects of the initiator and the culture that produce to it. This discourse is reflected in the form or figure of the object as well as the implicit meaning. Batik Demak is considered to be a cultural heritage in Demak since hundreds of years ago. It had, once, disappeared then in 2006 it was reappeared. This must cut the strings of history about the meaning and function of Batik Demak in ancient times. Batik Demak tends to present when each region in the territory of Indonesia, especially Central Java is promoting batik with regional motifs. The reinterpretation of symbols that emerge seems to be a strategy of branding or imaging an area. The meaning of the symbol of batik does not really represent the pattern of life of Demak community as manifested in the five typical motives of Demak.
\end{abstract}

Keywords: Batik Demak, Reinterpretation, Symbols

\section{Pendahuluan}

Kesenian hadir di tengah masyarakat untuk memenuhi kebutuhan jasmani dan rohani manusia. Sehingga hampir setiap aktivitas manusia dalam memenuhi kebutuhan tersebut, senantiasa dipenuhi dengan penghadiran bentuk kesenian. Kecenderungan masyarakat dalam mengungkapkan rasa keindahan ialah dengan melahirkan berbagai cabang seni. Salah satu cabang seni itu adalah seni rupa. Seni rupa dilihat dari segi matra ungkapnya adalah perpaduan antara garis, warna, dan bidang atau ruang. Dari sekian banyak cabang seni rupa, salah satu di antaranya adalah batik.

Nilai tradisi budaya yang nafasnya terhembus dalam seni rupa nusantara kental akan sifat ketimuran, artinya dasar-dasar pemikiran dalam pembuatan sebuah karya, lebih mengutamakan pemaknaan atau filosofinya, sehingga segi keindahan secara visual bukanlah prioritas yang utama. Dapat diartikan bahwa karya-karya budaya Indonesia memiliki estetika tinggi yang sering disebut adiluhung dan mempunyai nilai simbolis yang dalam. Hal tersebut dapat kita lihat salah satunya pada karya seni budaya Indonesia yang telah diakui dunia yaitu batik.

Batik Indonesia sebagai keseluruhan teknik, teknologi, serta pengembangan motif dan budaya yang terkait, oleh UNESCO telah ditetapkan sebagai Warisan Kemanusiaan untuk Budaya Lisan dan Non Bendawi (Masterpieces of the Oral and Intangible Heritage of Humanity) sejak 2 Oktober 2009. Batik, menurut Kamus Besar Bahasa Indonesia (Pusat Bahasa Departemen Pendidikan Nasional 2005:112), berarti kain yang digambar secara khusus dengan cara menuliskan malam pada kain dan pengolahannya diproses dengan cara tertentu.

Batik juga merupakan komoditas yang sangat menjanjikan dan memiliki peluang besar untuk dijadikan produk industri andalan Indonesia di kancah pasar dunia. Pada masa 
Masyarakat Ekonomi Asia (MEA) saat ini yang telah diterapkan sejak tahun 2016, persaingan perdagangan di jaringan masyarakat Asia semakin ketat. Dalam area pasar global, para indivi$\mathrm{du}$, lembaga ataupun kelompok tertentu tentlah harus mempersiapkan berbagai kekuatan modal atau kapital-kapital yang dimiliki agar mampu bertahan melawan persaingan. Hal tersebut senada dengan pernyataan Bourdieu bahwa modal berperan sebagai sebuah relasi sosial yang terdapat di dalam sebuah sistem pertukaran, dan istilah ini diperluas pada segala bentuk barang, baik materiil maupun simbol ${ }^{1}$, termasuk batik.

Sebagai salah satu penghasil batik pesisiran, Demak memiliki runtutan sejarah panjang tentang batiknya. Demak adalah salah satu kabupaten yang berada di pesisir utara Jawa Tengah dan dikenal sebagai Kerajaan Islam pertama di Jawa. Akan tetapi bukti sejarah tentang kerajaan Demak dan hasil budayanya banyak yang hilang tergerus jaman serta konflik perebutan kekuasaan di masa lampau. Salah satu hasil budaya yang masih dilestarikan yaitu batik bermotif sisik yang merupakan identitas batik Demak. Batik motif sisik ini sempat hilang selama ratusan tahun dari masyarakat Demak dan pada tahun 2006 batik ini muncul kembali. Tentulah terdapat komunikasi budaya yang hilang sehingga masyarakat Demak tidak tahu bagaimana fungsi dan makna dari ragam hias motif batik sisik itu sendiri. "Hilangnya" batik motif sisik dari Demak, dan baru dimunculkan kembali setelah ratusan tahun pastilah menjadikan pertanyaan besar bagi seorang peneliti, seperti kebenaran sejarah keberadaan tentang batik Demak hingga makna motif batik Demak itu sendiri.

Sebagai sebuah kerajaan Islam pertama di Jawa dan pusat kebudayaan Jawa di jamannya, pastilah batik Demak memiliki peran 'khusus' dalam menguak sejarah panjang perkembangan seni dan budaya Indonesia, khususnya seni Islam, lebih khusus lagi batik. Anggapan

1 Piere Bourdieu. 2009. Pengantar Paling Komperhensif terhadap Pemikiran Bordiue. Terjemahan. Yogyakarta: Jalasutra. Hlm. 27. tentang euphoria munculnya batik khas daerah, khususnya Demak, tentulah sesuatu yang patut dipertanyakan sebagai seorang peneliti tentang kebenaran keberadaan batik Demak hingga pemaknaan simbol dalam penggambaran motif batik Demak. Menyikapi kondisi yang demikian, ketertarikan ingin mempelajari, mengkaji, dan memahami lebih dalam tentang ragam hias batik Demak amatlah besar. Sebab hasil yang didapat dalam penelitian ini diharapkan mampu menguak hasil budaya bendawi hingga makna di dalamnya terkait simbol motif batik Demak.

Mengkaji Motif Batik Demak sebagai karya seni budaya, pada dasarnya berhadapan dengan tuntutan untuk melihat karya seni itu secara utuh, yang tidak lepas dari keinginan dan ideologi penggagas. Oleh karena itu perlu dipertanyakan bagaimana aspek-aspek kebudayaan eksternal memberikan pengaruh terhadap bentuk motif batik Demak dan maknanya dalam konsep pikir pembuat awalnya. Dalam kerangka khusus bagaimanakah keberadaan batik Demak dan bentuk visual batik Demak. Serta bagaimana simbolisme batik Demak serta implikasinya bagi masyarakat Demak kini.

\section{METODE PENELITIAN}

Batik Demak dipandang sebagai artifak yang berisikan wacana representasi diri yang dikerangkai budaya yang melahirkannya. Wacana ini tercermin melalui bentuk atau sosok objek pada batik Demak serta makna yang tersirat di balik bentuk artifak. Makna yang dicari merupakan makna eksistensial dari konteks penggagas. Penelitian dilakukan dengan mendapatkan data-data informasi yang ditekankan pada kualitas, maka jenis penelitian yang digunakan dipilih metode penelitian kualitatif. Fokus amatan dalam penelitian ini adalah: (1) Aspek perwujudannya; (2) Bentuk dan karakteristik visualnya; (3) ciri khas yang dimiliki; dan (4) Nilai-nilai atau makna implisit pada bentuk. Mengacu pada permasalahan tersebut, maka pendekatan yang digunakan adalah pendekatan kebudayaan, yaitu melihat batik Demak sebagai kebudayaan dan 
melihat batik Demak sebagai bagian yang tak terpisahkan dan bahkan menjadi inti dari kebudayaan masyarakat. Artifak sebagai hasil budaya tidak bisa dilepaskan dari tinjauan sejarah, sebab artifak tidak dapat lepas dari kerangka waktu yang menunjuk tingkat pemikiran dan kondisi sosio-kultural masyarakat Demak.

Data atau informasi berkenaan dengan batik Demak diperoleh melalui serangkaian langkah pengumpulan data. Pengumpulan data ini dilakukan melalui observasi ke desa Mlatiharjo dan desa Karangmlati, Kabupaten Demak, lokasi sentra pembuatan batik Demak yang berkembang sejak 2006 hingga dipertahankan sampai kini untuk melihat fisik batik Demak; studi pustaka, arsip, dan dokumen; dan wawancara mengenai batik Demak. Pengumpulan data, seleksi, hingga analisis data dilakukan secara terus-menerus dan berkelanjutan selama masa penelitian berlangsung.

Langkah pertama yang dilakukan untuk memperoleh data yang berkenaan dengan batik Demak ditempuh dengan cara mengamati objek secara seksama. Pengamatan terhadap objek dilakukan di desa Mlatiharjo dan Karangmlati, Demak, dimana batik Demak berkembang dan tetap dipertahankan eksistensinya hingga kini. Dalam melakukan observasi, peneliti mengamati langsung berbagai realitas yang ada di lapangan, di antaranya dari segi rupa secara langsung mengamati batik Demak sehingga dapat diketahui tentang berbagai hal yang terkait dengan rupa dan ihwalnya. Observasi tidak hanya mengamati, tetapi juga untuk mendokumentasikan data visual, khususnya batik Demak lengkap dengan detail motif dan teknik perwujudannya. Fakta-fakta yang direkam secara visual itu sangat membantu komprehensivitas data, dan terutama berguna untuk memperjelas deskripsi dan analisis terhadap data-data yang disajikan.

Langkah kedua yang dilakukan untuk memperoleh data atau informasi berkenaan dengan referensi ideal mengenai batik Demak dan pemikiran pemerintahan masa kerajaan Demak yang membuat awal ataupun pemerintahan Ka- bupaten Demak dalam menghadirkan kembali batik Demak dalam memprakarsai pembuatan batik Demak serta makna-makna simbolik yang tersirat dalam perwujudan bentuk. Langkah ini ditempuh dengan cara wawancara mendalam terhadap para narasumber, yaitu informan yang dianggap dapat memberikan keterangan atau informasi mengenai rupa dan makna batik Demak. Narasumber itu boleh jadi pembatik di desa Mlatiharjo dan Karangmlati atau pakar sejarah dan pakar seni Batik khas Demak di luar wilayah desa sentra batik Demak yang memahami mengenai aspek kesejarahan pembuatan batik Demak, visualisasi batik Demak hingga makna di balik rupa. Teknik wawancara ini dilakukan secara terbuka.

Wawancara yang dilakukan meliputi sejarah, teknik perwujudannya, hingga pengaruh-pengaruh yang mendorong terwujudnya batik Demak tersebut, dan makna menurut kerangka pemahaman budaya Jawa. Wawancara secara mendalam dengan arahan pertanyaan-pertanyaan yang diharapkan dapat membantu menggali data yang diperlukan. Wawancara diarahkan kepada informan yang dianggap dapat memberikan keterangan atau informasi tentang batik Demak, dengan tetap memperhatikan pertimbangan kriteria dan alasan pemilihan informasi, di antaranya dengan memperhatikan kredibilitas dan reputasi informan. Informan yang dijadikan sebagai narasumber berkait dengan aspek sejarah kemunculan dan penghadiran kembali batik Demak. Guna memahami seni batik Demak melalui sudut pandang seni rupa beserta makna motif dalam budaya Jawa, penulis meminta pendapat dari pakar seni Batik. Pendapat-pendapat dari para narasumber tersebut kemudian dikumpulkan bersama dengan data-data lain untuk kemudian dianalisis. Data yang diperoleh berupa latar belakang, rupa dan makna batik Demak. Wawancara dilakukan dengan pencatatan dan merekam hasil wawancara.

Studi pustaka dilakukan untuk mendapatkan informasi dan referensi dari sumber pustaka yang berkaitan dengan penelitian. Data-data 
tersebut berupa: buku, majalah, artikel, literatur, dan laporan penelitian yang tentunya terkait dengan kajian penelitian. Teknik pengumpulan data dimaksudkan untuk dapat menangkap informasi kualitatif dari sekian pihak berkait dengan rumusan masalah. Literatur yang digunakan sebagai acuan dan memiliki relevansi dengan topik penelitian antara: Clifford Geertz. Tafsir Kebudayaan. Yogyakarta: Penerbit Kanisius, 1992; Jakob Sumardjo. Estetika Paradoks. Bandung. Sunan Ambu Press. 2006; Dharsono. Budaya Nusantara; Kajian Konsep Mandala dan Konsep Tri-loka terhadap Pohon Hayat pada Batik Klasik, (Bandung: Rekayasa Sains, 2007; Denys Lombard. Nusa Jawa: Silang Budaya, Jakarta: PT Gramedia Pustaka Utama, 2000; Koentjaraningrat dalam Pengantar Ilmu Antropologi (1980) dan Kebudayaan Jawa (1994); Umar Kayam. Seni, Tradisi, dan Masyarakat. Jakarta: Penerbit Sinar Harapan, 1981, dan lain-lain. Data hasil observasi, dokumentasi, wawancara, pencatatan, dan studi pustaka akan dianalisis untuk mendapatkan keterangan dan informasi yang nantinya akan diarahkan untuk menjawab permasalahan yang dirumuskan.

Proses analisis data dilakukan sejak awal bersamaan proses pengumpulan data sehingga proses analisis data dilakukan secara terus-menerus dan berkelanjutan selama masa penelitian. ${ }^{2}$ Data yang berkenaan dengan batik Demak, baik sejarah maupun latar belakang pembuatannya yang didapat dari hasil wawancara, studi pustaka, dan dokumentasi direduksi untuk mendapatkan keterangan yang sesuai dengan pengungkapan simbol batik Demak dalam sudut pandang sang pembuat, yaitu pemerintahan masa kerajaan Demak. Hanya data yang relevan dengan objek yang diteliti dan dianggap penting dalam penulisan yang disajikan dan diverifikasi guna penarikan kesimpulan.

2 H.B. Sutopo. Metode Penelitian Kualitatif, Surakarta: UNS Press, 2002. 86-87.

\section{HASIL DAN PEMBAHASAN}

Anggapan masyarakat Jawa saat menggunakan batik dalam berbagai upacara adat merupakan cerminan dari kepribadian yang berkaitan erat dengan kepercayaan orang Jawa. Selain penutup tubuh atau sebagai tujuan dari kesopanan dan mempunyai nilai-nilai tata susila. Tradisi turun temurun dalam masyarakat Jawa tidak terlepas dari dua hal yaitu tatacara dan upacara. Tatacara diartikan sebagai proses jalannya upacara yang mempunyai aturan yang berurutan secara jelas, sedangkan upacara berarti ubarampe atau perlatan yang digunakan sebagai sarana. ${ }^{3}$

Hal tersebut ternyata juga berlaku dengan batik Demak, sebagai bagian dari batik pesisir, batik Demak berbeda dengan batik pedalaman seperti yang ada di Surakarta dan Yogyakarta yang penuh dengan bahasa simbol sang berisi tentang ajaran dan ujaran, atau tatanan yang tertulis dalam kain yang menjadi tuntunan dalam kehidupan. Sehingga pemakaian batiknya pun tidak boleh digunakan secara serampangan. Dalam batik Demak, ada beberapa yang mempercayai bahwa batik Demak pun memiliki makna simbol seperti batik pedalaman. Hal tersebut sebagaimana beberapa anggapan masyarakat dalam pola batiknya. Juga saat digunakan dalam sebuah acara ataupun kegiatan tertentu, hanya bedanya batik Demak lebih eksplisit dalam menguraikan simbol dibandingkan batik pedalaman. Batik yang akan di reinterpretasi tentunya lima motif batik yang disepakati oleh para pembatik Demak, yaitu:

3 Kalinggo Hanggopuro, Bathik Sebagai Busana dalam Tatanan dan Tuntunan, Yayasan Peduli Keraton Surakarta Hadiningrat, Surakarta,2002, hal. 103. 


\section{Motif Sisik}
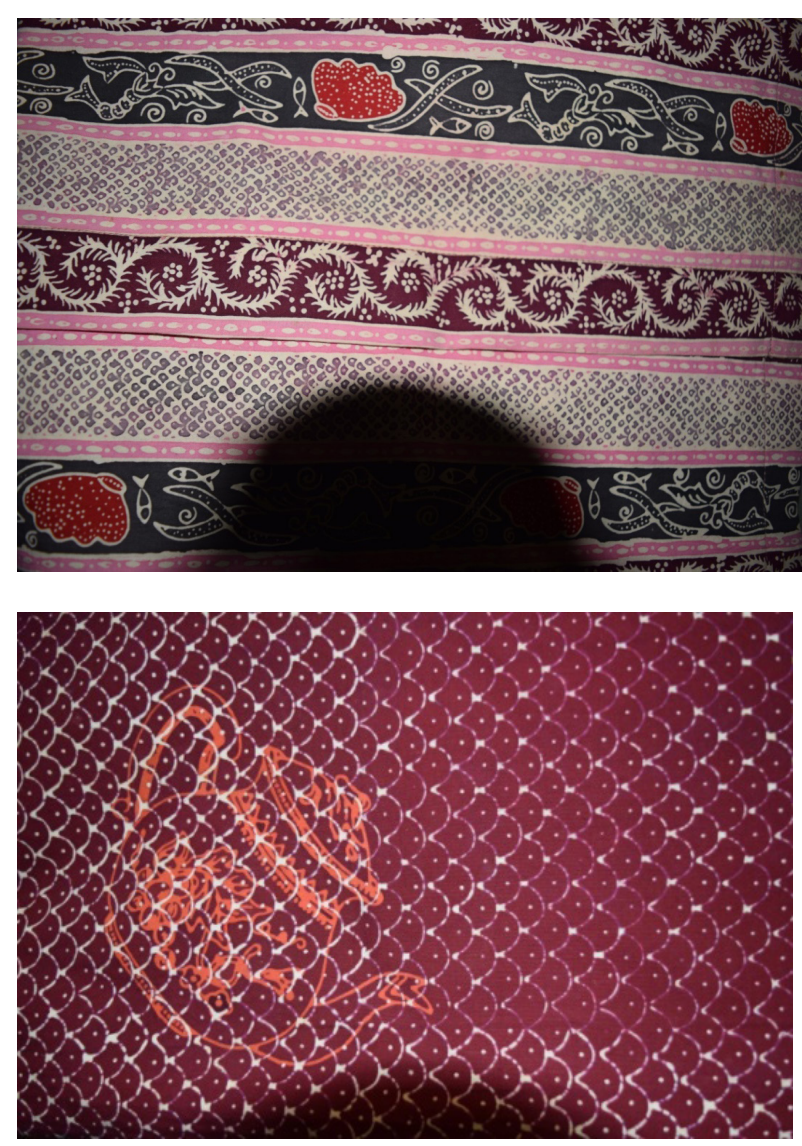

Gambar 1. Motif Sisik dalam berbagai pola Batik Demak

(Foto oleh : Afrizal, 2018)

Demak merupakan salah satu kabupaten di pesisir utara Jawa Tengah yang memiliki ragam hias batik pesisiran dengan bermacam-macam motifnya. Sebagai salah satu penghasil batik pesisiran, tentunya Demak memiliki runtutan sejarah tentang batiknya. Motif sisik pada batik khas Demak ini diambil karena sebagai media komunikasi visual yang memaparkan bahwa mayoritas penduduk Demak pada jaman dahulu bermata pencarian sebagai nelayan. Demak terkenal dengan hasil alam yang melimpah terutama dari hasil lautnya karena Demak memiliki wilayah laut yang cukup luas yang terletak di utara Jawa. Berdasarkan letak geografis tersebut, mayoritas penduduknya berprofesi sebagai nelayan. Hal ini sesuai yang diungkapkan oleh Ibu Dwi Marfiana yang menyebutkan
Sesuai informasi yang saya gali dan dapatkan asli pengakuan dari masyarakat sekitar pantai yaitu tepatnya di Desa Wedung, Demak. Dapat di ketahui bahwa jaman dahulu hingga sekarang ini, mayoritas penduduk sini bermata pencarian sebagai nelayan, karena hasil dari nelayanlah yang mereka andalkan dalam pemenuhan kebutuhan. Kenapa mereka lebih memilih nelayan, karena letak daerah mereka yang berada di dekat laut sehingga lebih menguntungkan dari pada bertani atau bercocok tanam. Pekerjaan bertani pada masyarakat sekitar dianggap pekerjaan sampingan ketika ada musim gelombang besar pada air laut. ${ }^{4}$

Berdasarkan dari pendapat di atas dapat ditarik kesimpulan bahwa pada jaman dahulu penduduk Demak mayoritas berprofesi sebagai nelayan dan pekerjaan petani dianggap sebagai pekerjaan sampingan ketika cuaca buruk yang nantinya dapat mempengaruhi gelombang laut yang tidak bisa diperkirakan arahnya. Dengan melimpahnya hasil laut terutama pada ikannya, masyarakat sekitar pada jaman itu menggambil sisik ikan sebagai bentuk pesan yang dituangkan dalam selembar kain batik. Ciri khas sisik yang terdapat pada batik Demak merupakan bentuk visual dari sisik yang terdapat pada tubuh ikan. Perbedaan sisik tersebut dengan sisik yang lain yaitu titik yang berada disetiap sisik-sisiknya. Titik hitam yang berada ditengah ini disebut sebagai telur ikan. Selain itu untuk membedakan dengan sisik ular (gingsing) atau naga, adalah pada semburat garis seperti pada sirip ikan.

Batik yang bermotif sisik ini lebih berkembang di wilayah Karangmlati, sebab selain pernah menjadi motif penciri batik Demak satu-satunya pada awalnya dan dikembangkan oleh Ibu Dwi Marfiana. Motif sisik juga lebih dekat dengan wilayah pesisir pantai yang lebih identik dengan Karangmlati, dibanding lokasi pembatik lain yang jauh dari pantai. Kegunaan batik sisik pada jaman dahulu digunakan sebagai

\footnotetext{
4 Wawancara dengan Ibu Dwi Marfiana, 7 Juli
} 
bawahan atau sarung pada saat melaut. Kepercayaan yang berkembang pada masyarakat Demak pada jaman dahulu mempercayai bahwa selembar kain yang bermotifkan sisik merupakan sebuah ungkapan doa'a kepada Tuhan Yang Maha Esa, agar saat melaut mendapatkan keselamatan dan memperoleh hasil tangkapan yang melimpah. Sebab sisik dianggap sebagai pelindung ikan dari kadar tingginya garam air laut, selain menjadi pelindung ikan dalam mengarungi samudera. Makna tersebut sama dengan motif sisik yang menjadi latar bagi ragam hias hasil pertanian Demak. Hal tersebut merupakan do'a bahwa pekerjaan sambilan dalam pertanian tidak pernah menggantikan pekerjaan utama sebagai nelayan. Pekerjaan di bidang pertanian pun juga diharapkan mendapatkan hasil yang baik selama pekerjaan melaut tidak dilakukan, mungkin karena cuaca atau suatu hal. Penggunaan motif sisik sering digunakan terutama saat prosesi larung sesaji dalam acara labuhan atau sedekah laut. Kain motif sisik biasanya digunakan sebagai layar perahu sesaji. Selain pada upacara labuhan laut juga pada tujuh hari pasca lebaran, yang disebut dengan bakda lomban. ${ }^{5}$ Pada prinsipnya motif sisik sama-sama digunakan sebagai do'a keselamatan dan agar mendapatkan hasil laut yang melimpah setelah acara dilaksanakan.

\section{Motif Jambu Blimbing}

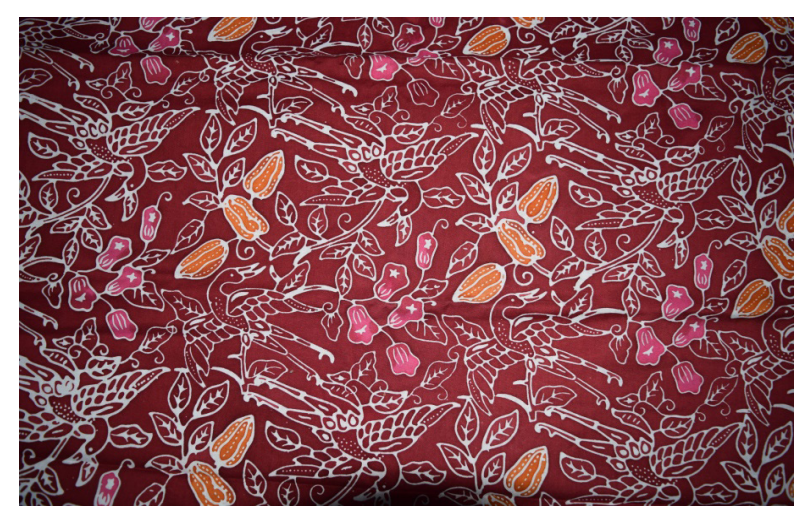

Gambar 2. Motif Jambu Blimbing "Mlatiharjan" (Foto oleh : Afrizal, 2018)

5 Wawancara dengan Bapak Hardono Budi Prasetyo, 7 Juli 2018
Motif Jambu Blimbing merupakan salah satu motif yang tetap eksis sebagai motif khas batik Demak, hasil pertanian kabupaten Demak yang menjadi penciri adalah Jambu air dan Belimbing. Kemunculan motif ini sebagai bagian dari pencarian ciri khas Demak agar batik yang dibuat, identik dengan kabupaten Demak. Buah Jambu air yang menjadi ciri khas Demak adalah Jambu Citra dan Jambu Delima. Sedangkan Belimbing telah lama menjadi buah khas dari kabupaten Demak.

Buah Jambu dan Belimbing pun memiliki makna simbol yang sering kali diidentikan dengan sholat lima waktu dan rukun Islam. Demak yang dikenal dengan sebutan 'Kota Wali' tentulah didominasi oleh masyarakat yang beraga Islam. Menurut perajin batik Mlatiharjan, bapak Arif Purwanto, bahwa penampang bawah jambu dan jumlah sisi belimbing yang lima merupakan sebuah amalan yang dapat mengantarkan masyarakat Demak mencapai keselamatan dunia dan akhirat, yaitu menjalankan rukun Islam, dimana sholat lima waktu ada di dalamnya. Purwanto menambahkan bahwa amalan yang akan dihisab pertama kali adalah sholatnya, dan sholat merupakan tiang agama. Jika seorang muslim tidak menjalankan sholat, maka dia sudah bukan lagi dianggap sebagai seorang muslim walau beragama Islam. Atau yang sering disebut dengan Islam KTP, jika seperti itu maka dapat dilihat perangai kehidupannya. Motif Jambu Blimbing ini dihadirkan agar manusia selalu ingat tentang perintah sholat dan rukun Islam yang menjadikan manusia yang menjalankan dengan baik akan mencapai tataran kehidupan dan kematian yang sempurna serta paripurna. Kehidupan yang sempurna yang dimaksud adalah ketentraman hati, sebab orang yang menjaga sholatnya akan dijaga oleh Allah SWT. Dan meninggal yang paripurna adalah ketika manusia selalu mengingat Allah SWT, maka dia akan meninggal dengan baik dan mendapat jaminan surga. ${ }^{6}$

Motif ini biasa digunakan sebagai mahar pernikahan, agar seorang imam keluarga mampu menjaga diri dan keluarganya dengan menegak-

6 Wawancara dengan Bapak Arif Purwanto, 20 Juli 2018, di rumahnya daerah Mlatiharjo, Gajah, Demak 
kan sholat, dan menjalankan perintah Allah dalam rukun Islam. Batik ini juga digunakan pada acara undangan pernikahan, dipakai para pemuka kampung sebagai syiar Islam melalui batik.

\section{Motif Glagahwangi}
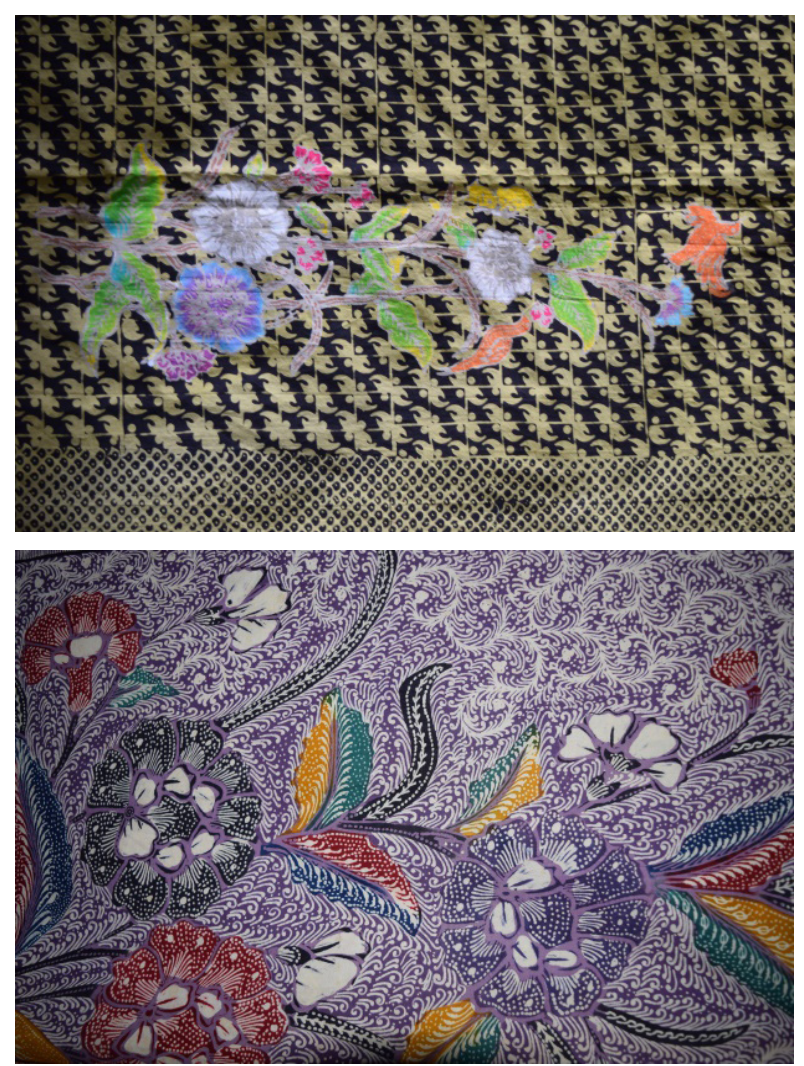

Gambar 3. Motif Glagahwangi milik UPPKS Karangmlati

(Foto : Wisnu Adisukma)

Motif Glagahwangi merupakan motif yang berpijak dari sejarah berdirinya Demak Bintoro. Dahulu Demak dikenal dengan daerah yang disebut Glagahwangi, diberi nama Glagahwangi oleh Raden Patah sebab menemukan pohon glagah yang berbau wangi. Masyarakat percaya bahwa tempat ditemukannya pohon glagah yang berbau wangi, kini tempat tersebut menjadi mihrab masjid Agung Demak. Menurut Hardono, atau biasa disapa Didik menyatakan bahwa penemuan batik Demak setelah ratusan tahun hilang adalah latar motif sisik dengan pola utama motif glagahwangi. Didik juga menunjukkan batik yang menjadi titik tolak perkembangan batik Demak yang ditemukan di Banyuwangi adalah motif Glagahwangi dengan latar sisik.

Motif Glagahwangi kini dijadikan sebagai batik khas Demak yang digunakan sebagai Pakaian Batik pegawai kabupaten, guru-guru dibawah dinas pendidikan kabupaten Demak, serta seragam siswa. Hal ini diharapkan agar seluruh elemen masyarakat Demak tidak melupakan sejarah. Selalu ingat awal dan asal sebagai masyarakat Demak, bahwa masyarakat Demak merupakan pembawa panji Islam penerus kekhalifahan Turki, yang senantiasa menjaga dan menyebarkan Islam di seluruh pelosok negeri. Dan agar selalu menggunakan filosofi Glagahwangi, walaupun tanaman glagah dianggap sebagai ilalang, namum memberikan bau yang harum bagi sekitarnya. Maknanya bahwa sebagai manusia Demak harus terus memberikan manfaat dan berguna meskipun diremehkan dan dinafikan orang lain. ${ }^{7}$

\section{Motif Lawang Bledeg}

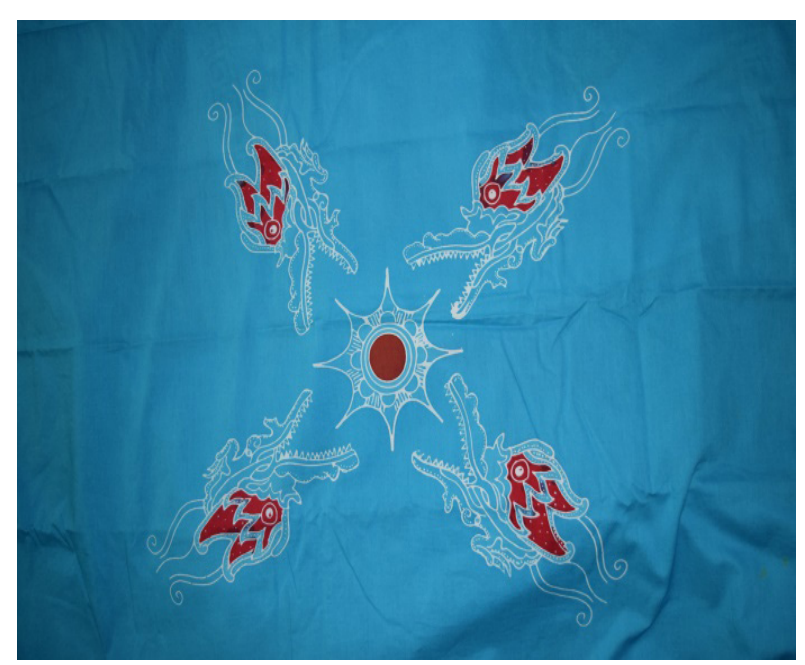

7 Wawancara dengan Hardono Budi Prasetyo, 7 Juli 2018 


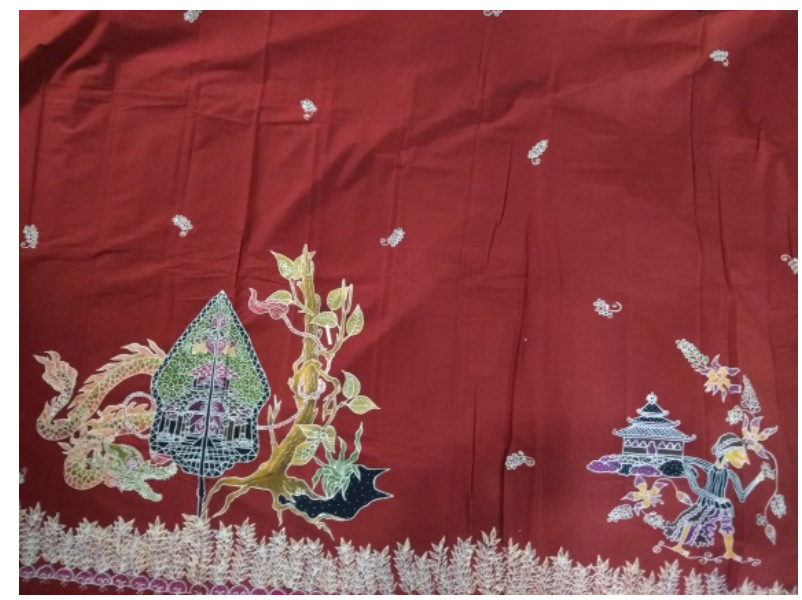

Gambar 4. Motif lawang bledeg versi cerita dan versi ragam hias

(Foto : Wisnu Adisukma)

Senada dengan Glagahwangi, motif lawang bledeg bersumber dari cerita sejarah saat Ki Ageng Selo menambatkan petir pada sebuah pohon gandri. Hal tersebut sangat sulit dinalar, bagaimana seorang manusia dapat melilitkan petir atau halilintar pada sebuah pohon. Banyak sejarahwan asli Demak yang membaca bahwa hal tersebut sebuah simbol tentang kehancuran Demak. Bahwasanya Sultan Trenggono tidak mampu menjaga wahyu tumurun, sebab menyerahkan pekerjaan ini pada Ki Ageng Selo. Justru ketika Ki Ageng Selo mampu menangkap petir mengungkapkan isyarat bahwa Ki Ageng Selo pelanjut kerajaan Demak nantinya. Hal tersebut terjadi saat keturunan Ki Ageng Selo, yaitu Ki Ageng Pemanahan memiliki putra bernama Sutowijoyo, yang kemudian mendirikan kerajaan Mataram Islam di kota Gede. ${ }^{8}$

Batik motif lawang bledeg lebih dikhususkan pada pengguna yang sudah berumur, bahwasanya filosofinya agar selalu ingat mati. Setiap orang tidak pernah tahu kapan nyawa dalam diri yang terikat akan dicabut. Namun ketika manusia mampu mengoptimalkan nyawa (kehidupan) yang ada dengan baik, maka akan mendapatkan kejayaan dalam hid-

8 Wawancara dengan Pak Walimin, 20 Juli 2018 di rumahnya daerah Kedungkoni, Mangunjiwan, Demak. up. Bledeg atau petir selalu digambarkan dengan sosok naga di setiap motif lawang bledeg. Naga dalam budaya timur dianggap binatang mitos yang membawa kemakmuran dan kejayaan. Dengan terus ingat pada kematian maka setiap manusia tidak akan pernah menyia-nyiakan waktu dan kesempatan hidupnya yang hanya sekali di dunia. ${ }^{9}$ Motif ini sengaja dirancang "berselera tua" sebab memang dikhususkan dipakai oleh yang berusia lanjut atau tidak lagi muda.

\section{Motif Masjid Agung Demak dan or- namennya}
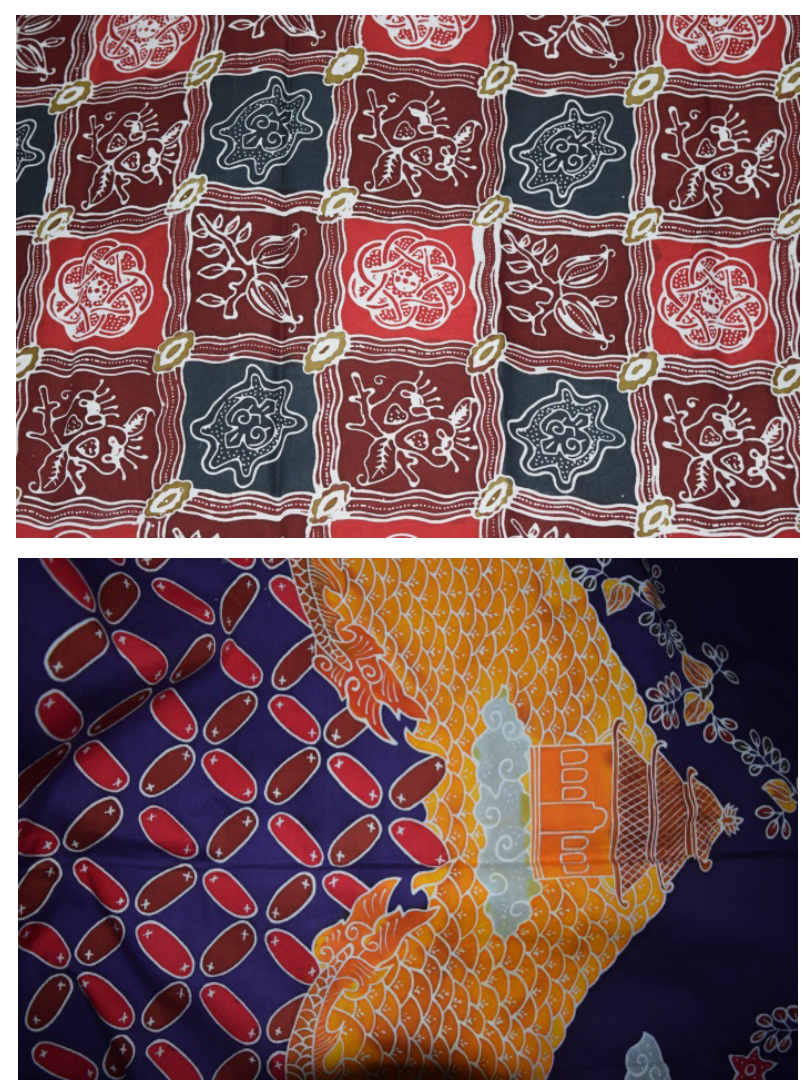

Gambar 5. Motif MAD (Masjid Agung Demak) dan ragam hiasnya

(Foto: Wisnu Adisukma)

Motif ini adalah yang terakhir muncul, yaitu pada tahun 2012 saat rapat penentuan motif khas Demak. Pemilihan motif ini lebih dikarenakan Masjid Agung Demak sebagai

9 Wawancara dengan Ibu Aminah, 20 Juli 2018, di rumahnya daerah Krapyak, Demak 
landmark Demak. Seolah akan kurang jika datang ke Demak namun tidak mampir ke Masjid Agung Demak. Pemunculan Masjid Agung Demak menjadi motif khas Demak juga ingin menggalai sejarah Demak bahwasanya Masjid Agung Demak merupakan bangunan monumental yang dibangun oleh para Walisongo.

Hal tersebut seperti yang dikatakan Arif Purwanto, bahwa Masjid Agung Demak merupakan bangunan yang hanya ada di Demak. Bangunan tersebut merupakan simbol kejayaan Islam di Jawa. Demak sebagai kota kecil patut bangga dan menggali kebanggaan sebab pernah menjadi kiblat budaya dan pusat pemerintahan di Nusantara, pasca runtuhnya Majapahit. Masjid Agung Demak juga menjadi simbol perjuangan Islam dalam melawan kolonialisme dan Imperealisme yang dilakukan Portugis. Serta perlawanan terhadap paham radikal seperti yang disebarkan oleh Syech Siti Jenar, Aryo Penangsang, dan sebagainya. Oleh karena itu motif Masjid Agung Demak dimunculkan agar masyarakat Demak mampu bangga dengan daerahnya, dan memotivasi diri untuk mengembalikan kejayaan Demak seperti pada masanya. ${ }^{10}$

Reinterpretasi simbol batik Demak mengubah pandangan simbol yang terungkap dalam batik Demak. Batik Demak yang dianggap merupakan warisan budaya yang ada di Demak sejak ratusan tahun silam. Seiring perkembangan jaman batik Demak pernah menghilang karena tergerus oleh jaman. Yang kemudian pada tahun 2006 batik Demak dimunculkan kembali. Hal tersebut pastilah memotong tali sejarah tentang makna dan fungsi batik Demak pada jaman dahulu. Kecenderungan kini, batik Demak hadir saat masingmasing daerah di wilayah Indonesia, khususnya Jawa Tengah sedang menggalakkan batik dengan motif khas daerah. Sehingga reinterpretasi simbol

10 Wawancara dengan Bapak Arif Purwanto, 20 Juli 2018 yang muncul adalah sebagai strategi branding atau pencitraan sebuah daerah. Pemaknaan simbol batik tidak benarbenar merepresentasikan pola kehidupan masyarakat

\section{KESIMPULAN}

Sebagai sebuah kerajaan Islam pertama di Jawa dan pusat kebudayaan Jawa di jamannya, pastilah batik Demak memiliki peran 'khusus' dalam menguak sejarah panjang perkembangan seni dan budaya Indonesia, khususnya seni Islam, lebih khusus lagi batik. Anggapan tentang euphoria munculnya batik khas daerah, khususnya Demak, tentulah sesuatu yang patut dipertanyakan sebagai seorang peneliti tentang kebenaran keberadaan batik Demak hingga pemaknaan simbol dalam penggambaran motif batik Demak. Menyikapi kondisi yang demikian, ketertarikan ingin mempelajari, mengkaji, dan memahami lebih dalam tentang ragam hias batik Demak amatlah besar.

Sejarah perjalanannya batik Demak banyak mendapat pengaruh budaya lain sehingga batik ini digolongkan sebagai karya multikultur. Batik Demak yang dibuat oleh pembatik Cina dikenal dengan batik saudagaran, yang mempunyai ciri khas kehalusan dan kerumitannya dengan isen-isennya. Sebagai bagian dari batik pesisir, batik Demak berbeda dengan batik pedalaman seperti yang ada di Surakarta dan Yogyakarta yang penuh dengan bahasa simbol sang berisi tentang ajaran dan ujaran, atau tatanan yang tertulis dalam kain yang menjadi tuntunan dalam kehidupan. Sehingga pemakaian batiknya pun tidak boleh digunakan secara serampangan. Dalam batik Demak, ada beberapa yang mempercayai bahwa batik Demak pun memiliki makna simbol seperti batik pedalaman. Hal tersebut sebagaimana beberapa anggapan masyarakat dalam pola batiknya. Juga saat digunakan dalam sebuah acara ataupun kegiatan tertentu, hanya bedanya batik Demak lebih eksplisit dalam menguraikan simbol dibandingkan batik pedalaman.

Melalui motif khas yang mengangkat Demak secara tidak langsung juga mengung- 
kapkan pesan secara visual tentang potensi alam dan landmark Demak. Melalui batik Demak sebagai salah satu media komunikasi yang mampu terbaca secara visual andaisaja dikerjakan secara serius oleh pemerintah kabupaten Demak, mampu menunjang sektor ekonomi yang secara tidak langsung juga memberikan dampak bagi pertumbuhan ekonomi masyarakat Demak. Perubahan mindset masyarakat untuk nguri-uri batik Demak dengan sebuah jargon mengembalikan Demak pada kejayaan, tentulah nostalgia dan pekerjaan yang tidak mudah. Pembangunan segala lini, baik pembangunan manusianya, infrastruktur, dan lain sebagainya ketika mampu bersinergi akan menjadikan Demak jauh lebih bai dari yang sekarang. Batik Demak pun mampu menjadi salah satu ujung tombak dalam pembukaan lapangan pekerjaan yang luas. Hal ini perlu ditunjang pelatihan serta kebijakan yang tegas. Sehingga simbol pada batik Demak mampu terealisasi sesuai dengan harapan yang tergambar dalam motif. Namun jika hanya sebagai media branding Demak, penulis sangsi bahwa Demak akan kembali jaya, terlebih batik Demak akan terus eksis.

\section{Daftar Pustaka}

Abdul Azis Said, Simbolisme Unsur Visual Rumah Tradisional Toraja dan Perubahan Aplikasinya pada Desain Modern, Yogyakarta: Ombak, 2004

Achmad Sjafi'i. 2007. "Bentuk Ragam Hias batik Pekalongan (Pencerminan Gaya "Subkultural" Pada Kria Tradisi)". Laporan Penelitian. ISI Surakarta.

Adi Kusrianto, 2017, Batik : Filsafat, Motif, dan Kegunaan, Yogyakarta: Penerbit Andi

Ari Wulandari, 2011, Makna Filosofis Batik Nusantara. Yogyakarta : Penerbit Andi.

Asti Musman dan Ambar B. Arini. 2011. Batik: Warisan Adiluhung Nusantara. Yogyakarta: Andi Publisher.
Bourdieu, Piere. 2009. Pengantar Paling Komperhensif terhadap Pemikiran Bordiue. Terjemahan. Yogyakarta: Jalasutra

Dwi Marianto, Seni Kritik Seni, Yogyakarta: Galang Press dan Yayasan Adhikarya untuk Pusat Penelitian Kebudayaan dan Perubahan Sosial, Universitas Gadjah Mada, 2000

Geertz, Clifford, The Interpretation of Cultures: Selected Essays, (New York: Basic Booc Inc., 1973

\section{ta: Kanisisus. 1992}

, Tafsir Kebudayaan. Yogyakar-

Graaf, H.J. De. dan TH. G. TH. Pigeaud, Kerajaan-Kerajaan Islam Pertama Di Jawa: Kajian Sejarah Politik Abad ke-15 dan ke-16, Jakarta: PT Pustaka Utama Grafiti Pers, 1985

Hasanudin. Batik pesisiran : Melacak Pengaruh Etos Dagang Santri pada Ragam Hias Batik. Bandung: Kiblat, 2001

H.B. Sutopo. Metode Penelitian Kualitatif, Surakarta: UNS Press, 2002.

Henry Sulistiono. 2012, "Ragam Hias Motif Sisik Batik Demak Sebagai Media Komunikasi Visual", Laporan Tugas Akhir Skripsi, Desain Komunikasi Visual, UDINUS Semarang.

Josef Prijotomo, Ideas and Form of Javanese Architecture, Yogyakarta: Gadjah Mada University, 1988

Kalinggo Hanggopuro, Bathik Sebagai Busana dalam Tatanan dan Tuntunan, Yayasan Peduli Keraton Surakarta Hadiningrat, Surakarta,2002

Kempers, A.J. Bernet, Ancient Indonesian Art, Cambridge, Massachusetts: Harvard University Press, 1959.

Koentjoroningrat, Kebudayaan Mentalitas dan Pembangunan. Jakarta: PT. Gramedia, 1997 
Kuper, Adam dan Jessica. 2000. Ensiklopedi Ilmu-ilmu Sosial. Jakarta: Rajawali Pers.

Lombard, Denys., Nusa Jawa Silang Budaya, Ed. II, Jakarta: Gramedia Pustaka Utama

Matthew, Miles dan Michael A. Huberman. Analisis Data Kualitatif. Jakarta. Universitas Indonesia. 1992.

M. Soerjani dan Bahrain Samad (ed.) Manusia dalam keserasian Lingkungan, Jakarta: Lembaga Penerbit Fakultas Ekonomi U.I, 1983

Norman K. Denzin dan Yvonna S.L. Handbook of Qualitative Research, Yogyakarta: Pustika Pelajar, 2009.

Soedarso Sp., Tinjauan Seni Sebuah Pengantar Untuk Apresiasi Seni, Yogyakarta: Saku Dayar Sana, 1987.

Spradley, James P., Metode Etnografi, Yogyakarta: Tiara Wacana, 1997

Sumadi Suryabrata, Metodologi Penelitian. Jakarta: Raja Grafindo Persada, 2012

Suwardi Endraswara. Metode, Teori, Teknik Penelitian Kebudayaan: Idiologi, Epistimologi dan Aplikasi. Yogyakarta: Pustaka Widya, 2006.

Timbul Haryono. 2008. Seni Pertunjukan dan Seni Rupa dalam Perspektif Arkeologi Seni. Surakarta: ISI Solo Press.

Tjetjep Rohendi Rohidi, “Ekspresi Seni Orang Miskin”, Disertasi Doktor Antropologi Universitas Indonesia Jakarta, 1993

Umar Kayam, Seni, Tradisi, Masyarakat, Jakarta: Sinar Harapan, 1981

Wisnu Adisukma, 2013, Simbolisme Ragam Hias Sisik Batik Demak, Jurnal Brikolase, Vol 5 No 2, Desember 2013, ISSN : 2087-0795, Institut Seni Indonesia (ISI) Surakarta
W.J.S. Poeradarminta, 2003. Kamus Umum Bahasa Indonesia. Jakarta: Balai Pustaka.

Wiyoso Yudoseputro, Jejak-jejak Tradisi Bahasa Rupa Indonesia Lama, Jakarta: Yayasan Seni Visual Indonesia, 2008

\section{Internet}

Adi Prasetijo "Konsep Kebudayaan Menurut Geertz". Dalam (http://etnobudaya.net/2008/04/01/konsep-kebudayaan-menurut-geertz/) Diakses pada 27 Maret 2018.

Wisnu Adisukma, Simbolisme Ragam Hias Sisik Batik Demak, http://jurnal.isi-ska. ac.id/index.php/brikolase/article/viewFile/415/415, diakses 26 Maret 2018

Tanpa Penulis, Teori Hermeneutik dalam http:// etnobudaya.net/2008/04/01/konsep-kebudayaan-menurut-geertz/ 27 Maret 2018 10.50

\section{Narasumber}

Ibu Dwi Marfiana (57 tahun), Ketua Klaster Batik Demak sekaligus ketua UPPKS Karangmlati serta Pegawai Disbudpar Kabupaten Demak

Bapak Hardono Budi Prasetyo (48 Tahun), Adik dari Ibu Dwi Marfiana dan pengelola pusat pelatihan batik Demak di Karangmlati

Bapak Arif Purwanto (44 Tahun), Perajin Batik Demak dan Ketua UPPKS Kembang Mlati di daerah Mlatiharjo, Gajah, Demak.

Pak Walimin (46 Tahun), perajin batik Demak di daerah Kedungkoni, Mangunjiwan, Demak.

Ibu Aminah (52 Tahun), perajin batik Demak dan pemilik usaha "Batik Bintoro" di daerah Krapyak, Demak 